\title{
Analysis of the Effect of Agency Problems on Sustainability Practices of Public Companies in Indonesia
}

\author{
Raden Rara Yulia Anindya Pranawaningsih and Eka Pria Anas \\ \{yuliaanindya@yahoo.com, ekapanas@yahoo.com\} \\ Magister Management Faculty of Economics and Business University of Indonesia \\ Salemba Raya 4, DKI Jakarta, Indonesia 10430, Phone: +62213103976
}

\begin{abstract}
The agency theory perspective of corporate social responsibility (CSR) considers CSR the manifestation of agency problems. It is related to the inefficiencies of corporate resources. On the other hand, good governance CSR regards a good-governed corporation as one that can reduce agency problems and usually has a high CSR rating. This study aims to analyze agency problems' effects on sustainability practices in Indonesia's public companies using a sample of 157 company-year observations over the 2014-2018 period and the regression method. We find that corporate cash holdings, free cash flow, and dividend payout ratio each have a significant positive effect on sustainability practices, while leverage has $a$ significant negative effect. This study also shows that there is no significant relationship between capital expenditure and sustainability practices. Overall, consistent with the view of good governance on CSR, companies that curb agency problems have high CSR ratings.
\end{abstract}

Keywords: Agency problem. Agency proxies. Corporate governance. Corporate social responsibility. Sustainability practices.

\section{Introduction}

Corporate awareness and engagement in sustainability practices, or Corporate Social Responsibility (CSR) activities, are considered very low in Indonesia, as is sustainability reporting. The data published by the Financial Services Authority (OJK) in 2017 stated that only 9\% of the Indonesian Stock 
Exchange (BEI) listed companies published their sustainability reports. According to Darwin [3], public companies are less enthusiastic about creating sustainability reports because creating sustainability reports means additional money and effort. Another reason is because there is no financial service authority regulation that obliges them to submit sustainability reports.

However, there is an increase in the number of companies that publish sustainability reports to OJK from year to year. Reasons include the issuance of the OJK regulation in 2017, the Government of Indonesia's suggestion to participate in the United Nations' Sustainable Development Goals agenda, and sustainability reporting awards that have become more prestigious. OJK issued regulation no.51/POJK.03/2017 in 2017, regarding sustainability for financial services institutions and public companies, including the preparation and submission of sustainability reports. Mandatory submission began in the 2019 reporting period for financial services institutions and will begin for public companies in 2020 .

CSR's good governance views socially responsible companies as those capable of maximizing the company's value with good corporate management practices. CSR activities can be run consistently with company activities in maximizing shareholder wealth and achieving broader social goals. According to Allen et al [4], well-governed firms that suffer less from agency concerns are more engaged in CSR activities. Caroline's [8] research shows companies' positive involvement with the environment produces new and competitive resources. Also, shareholders react positively to announcements of environmentally friendly initiatives and negatively to announcements of behavior 
that is damaging to the environment. There is also external pressure to become a "green" company by establishing institutional norms of CSR activities. Alexander et al [2] suggests that institutional investors encourage better corporate social and environmental performance throughout the world.

In contrast, the agency theory view regards CSR as an agency problem and a waste of company resources [4]. Adrian [1] argues that company managers can use CSR activities to collude with stakeholders to get higher managerial discretion (including cash) and extract personal benefits. Ronald et al [33] state that CSR donations are not purely a means of maximizing corporate value, but are manifestations of managerial agency problems. They found empirical evidence that the Chief Executive Officer (CEO) benefits from the company's donations and the CEO uses the company finances for personal interests that are less aligned with those of shareholders.

These contradictory views on CSR provide room for further research. Also, the number of studies examining the relationship between agency problems and sustainability practices in Indonesia is still quite limited. Research that examines CSR has been carried out in Indonesia but largely focused on the relation between CSR and companies' financial performance. Hence, the topic of agency problems and their relationship with CSR is unexplored.

In this paper, we test these two views by empirically examining the relationship between agency problem and companies' sustainability practices or Corporate Social Responsibility activities in Indonesia. Our study contributes to the existing empirical research related to agency problems and sustainability 
practices and reporting in Indonesia. Further, our results support the previous literature, which concludes that companies that can curb agency problems have a high rating of CSR activities. Thus, it provides information and references to management and shareholders regarding the benefit and implication of agency problem management and its relation to the sustainability practices' rating.

\section{Agency Theory and CSR: Hypotheses}

Michael and William [26] state that in the agency relationship, shareholders delegate the authority and responsibility to run the business to management, with the expectation that they will improve shareholder welfare. However, the interests of shareholders and management are not always aligned, which is called the agency problem. Agency problems will increase when management interests are not aligned with shareholders' interests, especially if management does not have a large portion of ownership of the company shares.

The perspective of CSR good governance is companies that care about environmental, economic, and social aspects are often better able to maximize the company's value by practicing good corporate management practices. A goodgoverned corporation that can reduce agency problems usually has a high CSR rating. In contrast, the agency theory considers CSR as the manifestation of agency problems and is related to the inefficiencies of corporate resources. Based on these perspectives and previous research, we formulate five hypotheses in this study.

\section{Cash holding and company sustainability practices}


According to Adrian [1], the agency's view on CSR argues that company managers can use CSR activities to collude with stakeholders to get higher managerial discretion (including cash) to extract personal benefits. In contrast, research conducted by Mohamed and Guillaume [28] suggests that money is significantly more significant if the company has a high CSR rating. Stakeholders regard companies that actively engage in sustainable practices as good companies, which tend to have more cash. Thus, the first hypothesis is as follows:

Ha1: Cash holding affects the company's sustainability practices.

\section{Capital expenditures and company sustainability practices}

Decision making related to capital expenditure is generally the company's primary consideration since it usually requires a lot of funds for a long-term period. According to Stephen et al [34], capital budgeting must be placed incrementally, which means that companies must properly consider opportunity costs and side effects in capital budgeting and ignore the sunk costs that occur. Concerning the company's sustainability practices, the budgeting of capital expenditure is related to CSR activities and causes companies to be more involved with CSR activities. This is in line with research conducted by Maretno [24], which states that CSR activities are related to corporate capital expenditure. Thus, the second hypothesis is as follows:

Ha2: Capital expenditures affect the company's sustainability practices.

Free cash flow and company sustainability practices 
Based on the free cash flow hypothesis, there is a massive conflict of interest between company managers and shareholders regarding payment policies when the company generates substantial free cash flow. Michael [25] emphasize that concerning agency problems, the shareholders' challenge is how to motivate managers to disburse cash (pay dividends) compared to investments with low returns or organizational inefficiencies. Based on Allen's research [4], higher CSR levels are caused by cash holdings, free cash flow, and higher capital expenditures. Thus, the third hypothesis is as follows:

Ha3: Free cash flow affects the company's sustainability practices.

Dividend payout ratio and company sustainability practices

According to Stephen et al [34], dividend payments should benefit shareholders by reducing managers' ability to use company resources inefficiently. From the perspective of agency theory, dividend payments play a role in controlling agency problems related to managing free cash flow. From the CSR perspective, good governance dividend payments can keep the interests of financial and non-financial stakeholders in line with the same goals. Mohammed [29] state that a high dividend payout strategy is likely to strengthen the company's reputation and show that the company cares about its stakeholders. Thus, the fourth hypothesis is as follows:

Ha4: A dividend payout ratio affects the company's sustainability practices. Leverage and company sustainability practices 
As the results of study [25], debt can curb agency costs from free cash flow by reducing the use of cash flows available by management. With high leverage, management tends to use company resources to pay debts to creditors, thereby reducing the possibility of waste of company resources [4]. Research conducted by Mohammed [29], who examined the relationship of leverage, dividends, and CSR, found evidence that companies with high leverage ratios are financially limited by lenders. Companies with high leverage have a low ability to pay dividends and are less involved in CSR activities. Based on the explanation, the fifth hypothesis is as follows:

Ha5: Leverage affects the company's sustainability practices.

\section{Data and Methodology}

\subsection{Sample Selection and Research Data}

The population in this study are all sustainability reports published by the non-financial sector of public companies in Indonesia. We obtain a total sample of 157 companies-year over 2014 to 2018 using purposive sampling technique by setting criteria to as follow:

1) Sustainability reports reported by public companies listed in the Indonesia Stock Exchange from 2014 to 2018.

2) Do not include the sustainability reports issued by the financial services sector. This study does not include sustainability reports from the financial 
sector, given the differences in the characteristics of its financial accounts compare to other industries.

3) Do not include the sustainability report that the company has negative equity at the respective period to mitigate bias.

4) Do not include the sustainability report that the company records losses at the respective period to mitigate bias.

The operational variables can be seen in Table 3.1. Based on Clara et al [10], the most common proxies used for agency problems in previous studies are free cash flow, as used in Jensen's research in 1986, Stulz in 1990, Shleifer and Vishny in 1997 and Titman et al. in 2004, Richardson in 2006 and Masulis et al. in 2007. Five proxies for agency problems, namely cash holdings, capital expenditures, free cash flow, dividend payout ratios, and leverage have been used in past research [4]. Based on the above literature, this study uses cash holdings, capital expenditures, free cash flow, dividend payout ratios, and leverage as a proxy for agencies' problems.

The sustainability disclosure indicators used in this study are Environmental, Social, and Governance (ESG) ratings, which are converted from ESG ratings obtained from the Thomson Reuters database. The use of data from Thomson Reuters is considered accurate and reliable, has a range of global sustainability reports, including in Indonesia. In addition, the Thomson Reuters methodology has been tested and widely recognized by global investors and academics. Thus, the use of the data does not cause bias and can mitigate calculation errors when doing manual input (self-assessment of CSR reports). Thomson Reuters analyzes and evaluates company sustainability reports globally 
based on more than 450 ESG metrics in each sustainability report. These 450 ESG metrics are then grouped into ten categories consisting of three main aspects, namely, social, environmental, and governance aspects [7]. After evaluating certain weights, a value of ESC score is given from 1 to 100 . Then the ESG score will be converted by Thomson Reuters into a grade with a range from $\mathrm{D}$ - to $\mathrm{A}+$ based on a predetermined scale.

We used control variables to limit the influence of other factors in the study. The independent variable, the dependent variable, and the control variable in this study refer to the research variables used in the Allen et al [4] research in 2016 and Mohammed [29] in 2019.

\subsection{Empirical design and testing}

This study uses SPSS 23 (Statistical Package for the Social Sciences) to analyze and test the research data. Methods of the empirical testing in this study include: descriptive statistics that describe the information or data characteristics; the classical assumption test to ensure that there are no violations of the classical assumptions that underlie the regression model in this study; and the multiple regression to test the hypotheses and analyze the effect of five proxies of agency problems (independent variables) on the practice of sustainability or CSR activities (dependent variable) of Indonesia's public companies. There are five regression models in this study (model A, model B, model C, model D, and model E), each of which explained the effect of each independent variable on the dependent variable using similar control variables. Regression equations for the five models are as follow. 
Table 3.1. Variable Measurement and Definitions

\begin{tabular}{|c|c|c|}
\hline & Research variables & Measurement Criteria \\
\hline \multicolumn{3}{|l|}{ Dependent variable } \\
\hline ESG & $\begin{array}{l}\text { The ratings of the company's } \\
\text { sustainability practices }\end{array}$ & $\begin{array}{l}\text { The company ESG grades from Thomson } \\
\text { Reuters }\end{array}$ \\
\hline \multicolumn{3}{|l|}{ Independent } \\
\hline \multicolumn{3}{|l|}{ variables } \\
\hline CASH & Cash holding & $\begin{array}{l}\text { Cash and cash equivalents divided by total } \\
\text { assets }\end{array}$ \\
\hline CAPEX & Capital expenditures & Capital expenditure divided by total assets. \\
\hline FCF & Free cash flow & $\begin{array}{l}\text { EBIT plus depreciation and amortization } \\
\text { minus by changes in working capital and } \\
\text { capital expenditure, then the results are } \\
\text { divided by total assets }\end{array}$ \\
\hline DPR & Dividend payout ratio & Dividends divided by net income \\
\hline LEV & Leverage & Total liabilities divided by total equity \\
\hline \multicolumn{3}{|l|}{ Control variables } \\
\hline TOBINSQ & $\begin{array}{l}\text { Market to book ratio (Tobin's } \\
\text { Q) }\end{array}$ & $\begin{array}{l}\text { The market value of equity divided by the } \\
\text { book value of equity }\end{array}$ \\
\hline LN_SIZE & Ukuran perusahaan & Natural logarithm (Ln) of total assets \\
\hline ROE & Return on equity & $\begin{array}{l}\text { Net income is divided by the average total } \\
\text { equity of the year and previous year }\end{array}$ \\
\hline
\end{tabular}


Table 3.2. Regression Equations Model A, B, C, D, E

\begin{tabular}{|c|c|c|}
\hline Model & $\begin{array}{c}\text { Independent } \\
\text { variables }\end{array}$ & Regression Equations \\
\hline $\mathrm{A}$ & $\mathrm{CASH}$ & $\mathrm{ESG}=\alpha+\beta 1 \mathrm{TOBINSQ}+\beta 2 \mathrm{LN} \_\mathrm{SIZE}+\beta 3 \mathrm{ROE}+\beta 4 \mathrm{CASH}+\varepsilon$ \\
\hline $\mathrm{B}$ & $\mathrm{CAPEX}$ & $\mathrm{ESG}=\alpha+\beta 1 \mathrm{TOBINSQ}+\beta 2 \mathrm{LN} \_\mathrm{SIZE}+\beta 3 \mathrm{ROE}+\beta 4 \mathrm{CAPEX}+\varepsilon$ \\
\hline $\mathrm{C}$ & $\mathrm{FCF}$ & $\mathrm{ESG}=\alpha+\beta 1 \mathrm{TOBINSQ}+\beta 2 \mathrm{LN}$ _SIZE $+\beta 3 \mathrm{ROE}+\beta 4 \mathrm{FCF}+\varepsilon$ \\
\hline $\mathrm{D}$ & $\mathrm{DPR}$ & $\mathrm{ESG}=\alpha+\beta 1$ TOBINSQ $+\beta 2 \mathrm{LN} \_\mathrm{SIZE}+\beta 3 \mathrm{ROE}+\beta 4 \mathrm{DPR}+\varepsilon$ \\
\hline $\mathrm{E}$ & $\mathrm{LEV}$ & $\mathrm{ESG}=\alpha+\beta 1$ TOBINSQ $+\beta 2 \mathrm{LN} \_\mathrm{SIZE}+\beta 3 \mathrm{ROE}+\beta 4 \mathrm{LEV}+\varepsilon$ \\
\hline
\end{tabular}

\section{$4 \quad$ Results and Discussions}

\subsection{Descriptive Statistics}

The descriptive statistics show that the average sustainability rating in Indonesia is 5.29 or $\mathrm{C}$ rating. The average sustainability report rating is still considered low in Indonesia. The average cash holdings and cash flow during 2014-2018 are $12 \%$ and $10 \%$, respectively. The average ratio of capital expenditure to company assets is $6 \%$; that also considered low, most likely because the idle cash is used mainly for dividend payments. The average dividend payout ratio is $51 \%$, with the lowest ratio at $1 \%$ and the highest at $186 \%$. The ratio shows that Indonesian companies tend to make quite large dividend payments, with an average of $51 \%$ of company profits. The average of companies' leverage is at $1.78 \mathrm{x}$, which is considered high. The average ROE of the company is $27 \%$ and thought to be quite good. 
Table 4.1.Descriptive Statistics

\begin{tabular}{|l|l|l|l|l|l|}
\hline & N & Minimum & Maximum & Mean & $\begin{array}{l}\text { Std. } \\
\text { Deviation }\end{array}$ \\
\hline ESG & 157 & 1.00 & 10.00 & 5.29 & 2.39 \\
\hline CASH & 157 & 0.00 & 0.39 & 0.12 & 0.09 \\
\hline CAPEX & 156 & 0.00 & 0.22 & 0.06 & 0.05 \\
\hline FCF & 157 & -0.19 & 0.74 & 0.10 & 0.15 \\
\hline DPR & 142 & 0.01 & 1.86 & 0.51 & 0.33 \\
\hline LEV & 157 & 0.14 & 20.43 & 1.78 & 2.75 \\
\hline TOBINSQ & 157 & 0.37 & 322.46 & 7.67 & 27.79 \\
\hline LN_SIZE & 157 & 28.86 & 33.47 & 1.17 & 0.89 \\
\hline ROE & 147 & 0.00 & 2.81 & 0.27 & 0.37 \\
\hline
\end{tabular}

\subsection{The Classical Assumption Test Analysis}

\subsubsection{Normality Test Analysis}

Using the Kolmogorov-Smirnov One-Sample Test, the results show that the Asymp value. Sig. (2-tailed) of 0.20 is above the significance value (0.05); therefore, we can conclude that the regression model has a normal distribution.

Table 4.2. Kolmogorov-Smirnov Normality Test Results

\begin{tabular}{|l|l|c|}
\hline \multicolumn{2}{|l|}{} & $\begin{array}{c}\text { Unstandardized } \\
\text { Residual }\end{array}$ \\
\hline $\mathrm{N}$ & Mean & 0.00 \\
\cline { 2 - 3 } $\begin{array}{l}\text { Normal } \\
\text { Parametersa,b }\end{array}$ & Std. Deviation & 1.95 \\
\hline $\begin{array}{l}\text { Most Extreme } \\
\text { Differences }\end{array}$ & Absolute & 0.06 \\
\cline { 2 - 3 } & Positive & 0.06 \\
\cline { 2 - 3 } & Negative & -0.04 \\
\hline Test Statistic & 0.06 \\
\hline Asymp. Sig. (2-tailed) & $\mathbf{0 . 2 0}$ \\
\hline
\end{tabular}

\subsubsection{Heteroscedasticity Test Analysis}


The Glejser Test the results show the significant value of all independent and control variables is above 0.05. Thus, there are no symptoms of heteroscedasticity in the research regression model.

Table 4.3. Heteroscedasticity Test Results

\begin{tabular}{|l|c|c|}
\hline VARIABLE & SIGNIFICANCE & TEST RESULT \\
\hline CASH & 0.80 & There is no heteroscedasticity. \\
\hline CAPEX & 0.52 & There is no heteroscedasticity. \\
\hline FCF & 0.22 & There is no heteroscedasticity. \\
\hline DPR & 0.20 & There is no heteroscedasticity. \\
\hline LEV & 0.23 & There is no heteroscedasticity. \\
\hline TOBINSQ & 0.54 & There is no heteroscedasticity. \\
\hline LN_SIZE & 0.74 & There is no heteroscedasticity. \\
\hline ROE & 0.35 & There is no heteroscedasticity. \\
\hline
\end{tabular}

\subsubsection{Multicollinearity Test Analysis}

The test results indicate that each of the variables tested has a VIF value of less than 10 , and the tolerance value is above 0.10 , so there is no multicollinearity in this regression model.

Table 4.4. Multicollinearity Test Results

\begin{tabular}{|l|c|c|c|}
\hline \multirow{2}{*}{ VARIABLE } & \multicolumn{2}{|c|}{$\begin{array}{c}\text { Collinearity } \\
\text { Statistics }\end{array}$} & \multirow{2}{*}{ TEST RESULT } \\
\cline { 2 - 3 } & Tolerance & VIF & \\
\hline CASH & 0.89 & 1.12 & There is no multicollinearity. \\
\hline CAPEX & 0.93 & 1.08 & There is no multicollinearity. \\
\hline FCF & 0.32 & 3.15 & There is no multicollinearity. \\
\hline DPR & 0.81 & 1.24 & There is no multicollinearity. \\
\hline LEV & 0.42 & 2.45 & There is no multicollinearity. \\
\hline TOBINSQ & 0.25 & 3.99 & There is no multicollinearity. \\
\hline LN_SIZE & 0.73 & 1.36 & There is no multicollinearity. \\
\hline
\end{tabular}

\subsection{Hypothesis Testing Results and Discussion}


Multiple Linear Regression analysis was performed to examine the effect of agency problem proxies on company sustainability practices. The following tables provide a summary of the results of multiple regression and regression equations for model A to model E.

Table 4.5. Regression Equations After Multiple Regression Test

\begin{tabular}{|c|c|c|}
\hline Model & $\begin{array}{c}\text { Independent } \\
\text { variables }\end{array}$ & Regression Equations \\
\hline A & $\mathrm{CASH}$ & $\begin{array}{c}\mathrm{ESG}=-8.46-0.01 \mathrm{TOBINSQ}+0.39 \mathrm{LN} \_\mathrm{SIZE}+ \\
1.85 \mathrm{ROE}+9.87 \mathrm{CASH}\end{array}$ \\
\hline $\mathrm{B}$ & CAPEX & $\begin{array}{c}\mathrm{ESG}=0.48-0.01 \mathrm{TOBINSQ}+0.13 \mathrm{LN} \text { _SIZE }+1.52 \mathrm{ROE} \\
+6.08 \mathrm{CAPEX}\end{array}$ \\
\hline $\mathrm{C}$ & FCF & $\begin{array}{c}\mathrm{ESG}=-7.49-0.01 \mathrm{TOBINSQ}+0.40 \mathrm{LN} \text { SIZE }+ \\
0.45 \mathrm{ROE}+4.74 \mathrm{FCF}\end{array}$ \\
\hline $\mathrm{D}$ & DPR & $\begin{array}{c}\mathrm{ESG}=-5.90-0.01 \mathrm{TOBINSQ}+0.31 \mathrm{LN} \_ \text {SIZE }+ \\
1.88 \mathrm{ROE}+1.85 \mathrm{DPR}\end{array}$ \\
\hline $\mathrm{E}$ & LEV & $\begin{array}{c}\mathrm{ESG}=-10.12-0.00 \mathrm{TOBINSQ}+0.49 \mathrm{LN} \_\mathrm{SIZE}+ \\
\text { 3.18ROE }-0.38 \mathrm{LEV}\end{array}$ \\
\hline
\end{tabular}

Table 4.6. Summary of Multiple Regression Results

\begin{tabular}{lcccccc}
\hline Variables & Simultaneous & $\begin{array}{c}\text { Model } \\
\text { A }\end{array}$ & $\begin{array}{c}\text { Model } \\
\text { B }\end{array}$ & $\begin{array}{c}\text { Model } \\
\text { C }\end{array}$ & $\begin{array}{c}\text { Model } \\
\text { D }\end{array}$ & $\begin{array}{c}\text { Model } \\
\text { E }\end{array}$ \\
\hline Constant & -10.93 & -8.46 & 0.48 & -7.49 & -5.90 & -10.12 \\
& $(6.92)$ & $(7.05)$ & $(7.61)$ & $(7.51)$ & $(7.33)$ & $(7.21)$ \\
& & & & & & \\
Control & & & & & & \\
Variables & & & & & & \\
TOBINSQ & 0.00 & -0.01 & -0.01 & -0.01 & -0.01 & 0.00 \\
& $(0.01)$ & $(0.01)$ & $(0.01)$ & $(0.01)$ & $(0.01)$ & $(0.01)$ \\
LN_SIZE & $0.45^{*}$ & 0.39 & 0.13 & 0.40 & 0.31 & $0.49^{*}$ \\
& $(0.22)$ & $(0.22)$ & $(0.24)$ & $(0.24)$ & $(0.23)$ & $(0.23)$ \\
ROE & 2.15 & $1.85^{*}$ & 1.52 & 0.45 & 1.88 & $3.18^{*}$ \\
& $(1.26)$ & $(0.82)$ & $(0.87)$ & $(0.94)$ & $(1.10)$ & $(0.91)$
\end{tabular}

Agency Problem Proxies

$\begin{array}{rrr}\text { CASH } & 8.39^{*} & 9.87^{*} \\ & (2.09) & (2.13)\end{array}$




\begin{tabular}{|c|c|c|c|c|c|c|}
\hline \multirow[t]{2}{*}{ CAPEX } & 7.29 & & 6.08 & & & \\
\hline & (3.92) & & $(4.35)$ & & & \\
\hline \multirow[t]{2}{*}{ FCF } & 1.59 & & & $4.74^{*}$ & & \\
\hline & $(2.00)$ & & & (1.74) & & \\
\hline \multirow[t]{2}{*}{ DPR } & 0.80 & & & & $1.85^{*}$ & \\
\hline & $(0.61)$ & & & & $(0.62)$ & \\
\hline \multirow[t]{2}{*}{ LEV } & $-0.27^{*}$ & & & & & $0.38^{*}$ \\
\hline & $(0.11)$ & & & & & $(0.09)$ \\
\hline $\begin{array}{l}\text { Number of } \\
\text { observations }\end{array}$ & 157 & 157 & 157 & 157 & 157 & 157 \\
\hline R-squared & 0.32 & 0.15 & 0.04 & 0.07 & 0.11 & 0.14 \\
\hline
\end{tabular}

\subsubsection{Cash holdings and company's sustainability practices}

From the results of the regression in Table 4.7, the $t$ count is greater than the $\mathrm{t}$ table $(\mathrm{df}>120, \alpha=0.05, \mathrm{t}$ table $=1.645)$, and the level of significance is smaller than 0.05. Hence, H01 is rejected. Cash holding has a significant effect on the company's sustainability with a positive relationship, which is indicated by the coefficient value $\beta=9.871$.

Table 4.7. Model A Multiple Regression Results

\begin{tabular}{|c|l|r|r|r|r|r|}
\hline \multirow{3}{*}{ Model } & & \multicolumn{2}{|c|}{$\begin{array}{c}\text { Unstandardized } \\
\text { Coefficients }\end{array}$} & $\begin{array}{c}\text { Standardized } \\
\text { Coefficients }\end{array}$ & \multirow{2}{*}{ T } & \multirow{2}{*}{ Sig. } \\
\cline { 3 - 6 } & & \multicolumn{1}{c|}{$\mathrm{B}$} & $\begin{array}{c}\text { Std. } \\
\text { Error }\end{array}$ & \multicolumn{1}{c|}{ Beta } & & \\
\hline \multirow{3}{*}{$\mathrm{A}$} & (Constant) & -8.455 & 7.051 & & -1.199 & 0.232 \\
\cline { 2 - 7 } & TOBINSQ & -0.011 & 0.010 & -0.137 & -1.108 & 0.270 \\
\cline { 2 - 7 } & LN_SIZE & 0.390 & 0.223 & 0.148 & 1.752 & 0.082 \\
\cline { 2 - 7 } & ROE & 1.851 & 0.821 & 0.288 & 2.255 & 0.026 \\
\hline
\end{tabular}




\begin{tabular}{|l|l|l|l|l|l|}
\hline CASH & 9.871 & 2.126 & 0.364 & 4.642 & 0.000 \\
\hline a. Dependent Variable: ESG \\
\hline
\end{tabular}

In general, the abundant cash holdings imply possible agency problems. Management can use abundant funds for their interests, which might not be in line with shareholders' interests. However, high cash holdings do not always indicate the agency problems. This is consistent with the research by Allen et al [4] which states that higher cash holdings, free cash flow, and capital expenditure do not always reflect agency costs as long as there are sufficient growth and investment opportunities. In this study, the average return on investment (ROE) of the company is considered high, with an average return of $27 \%$. Besides, cash dividend payments to the shareholders are quite high, with an average of $51 \%$ of the company's net profit. Thus, companies in Indonesia are well managed in terms of investment and cash ownership.

Other studies that support the results of this study are those by Mohamed [28] and Adrian [1], which suggest that cash is significantly greater if the company has a high CSR rating. According to Mohamed [28], the existence of excess cash in companies with high CSR ratings is because investors consider that CSR allows managers to increase shareholder wealth by increasing the efficiency of using cash resources. According to Adrian [1], the role of corporate governance towards CSR implies that CSR is effective in reducing agency problems related to cash ownership decisions.

\subsubsection{Capital expenditures and company's sustainability practices}


From the results of the regression in Table 4.8, the $\mathrm{t}$ table is greater than $\mathrm{T}$ arithmetic $(\mathrm{df}>120, \alpha=0.05, \mathrm{t}$ table $=1.645)$ and has a significance level greater than 0.05 . Thus, $\mathrm{H} 02$ is accepted, so capital expenditures do not significantly influence the company's sustainability practices.

Maretno [24] argues that CSR activities are significantly related to capital expenditure. CSR activities increase capital expenditures for property, factories, and equipment to reduce pollution and waste, increase energy efficiency, and meet regulatory requirements. In the United States and Europe, there are environmental regulations that cause companies to dedicate capital expenditures for CSR purposes. The company spends capital on building environmentallyfriendly factories or equipment, reducing emissions and pollution, reducing waste, and improving energy efficiency. However, this is different from the conditions in Indonesia. In the study period, the OJK has not enforced the regulations regarding the obligation to conduct and report sustainability reports.

Table 4.8. Model B Multiple Regression Results

\begin{tabular}{|c|c|c|c|c|c|c|}
\hline \multirow{3}{*}{ Model } & & \multicolumn{2}{|c|}{$\begin{array}{c}\text { Unstandardized } \\
\text { Coefficients }\end{array}$} & $\begin{array}{c}\text { Standardized } \\
\text { Coefficients }\end{array}$ & \multirow{2}{*}{ T } & \multirow{2}{*}{ Sig. } \\
\cline { 3 - 7 } & & $\mathrm{B}$ & $\begin{array}{c}\text { Std. } \\
\text { Error }\end{array}$ & Beta & \\
\hline \multirow{5}{*}{ B } & (Constant) & 0.480 & 7.613 & & 0.063 & 0.950 \\
\cline { 2 - 7 } & TOBINSQ & -0.010 & 0.011 & -0.120 & -0.902 & 0.369 \\
\cline { 2 - 7 } & LN_SIZE & 0.134 & 0.244 & 0.050 & 0.550 & 0.583 \\
\cline { 2 - 7 } & ROE & 1.519 & 0.874 & 0.237 & 1.739 & 0.084 \\
\cline { 2 - 7 } & CAPEX & 6.084 & 4.353 & 0.118 & 1.398 & 0.164 \\
\hline
\end{tabular}


Also, decision making regarding capital expenditure in Indonesia is generally a major concern for companies because capital expenditure requires high costs and is a long-term investment. Based on the results of descriptive statistics, the average capital expenditure (capital expenditure) of the company is only $6 \%$ of total assets. Thus, capital expenditure for companies in Indonesia is more for long-term capital expenditures and investments that support the company's long-term operations. The descriptive statistics indicate that the expenditure on CSR activities carried out by the company is now more short-term so that capital expenditure does not affect CSR activities.

\subsubsection{Free cash flows and company's sustainability practices}

From the regression results in table 4.9, $\mathrm{t}$ count is greater than the table $(\mathrm{df}>120, \alpha=0.05, \mathrm{t}$ table $=1.645)$, and the level of significance is smaller than 0.05. Thus, H03 is rejected, so free cash flow has a significant effect on the company's sustainability practices with a positive relationship.

Table 4.9. Model C Multiple Regression Results

\begin{tabular}{|c|c|c|c|c|c|c|}
\hline \multirow{2}{*}{ Model } & & \multicolumn{2}{|c|}{$\begin{array}{l}\text { Unstandardized } \\
\text { Coefficients }\end{array}$} & \multirow{2}{*}{$\begin{array}{c}\text { Standardized } \\
\text { Coefficients } \\
\text { Beta }\end{array}$} & \multirow{2}{*}{$\mathrm{T}$} & \multirow{2}{*}{ Sig. } \\
\hline & & B & $\begin{array}{l}\text { Std. } \\
\text { Error }\end{array}$ & & & \\
\hline \multirow{5}{*}{$\mathrm{C}$} & (Constant) & -7.491 & 7.509 & & -0.998 & 0.320 \\
\hline & TOBINSQ & -0.010 & 0.011 & -0.123 & -0.951 & 0.343 \\
\hline & LN_SIZE & 0.395 & 0.238 & 0.150 & 1.659 & 0.099 \\
\hline & ROE & 0.449 & 0.941 & 0.070 & 0.478 & 0.634 \\
\hline & $\mathrm{FCF}$ & 4.742 & 1.743 & 0.308 & 2.721 & 0.007 \\
\hline
\end{tabular}


According to Michael [25], there is a huge conflict of interest between shareholders and managers about payment policies when the organization generates substantial free cash flow. Concerning agency problems, the difficulty faced by shareholders is how to motivate managers to disburse cash (provide dividends) compared to investing in investments that have low capital costs or throwing them away at organizational inefficiencies. This is in line with the research of Ronald [33]. They support agency theory and find empirical evidence in their research that giving a company is not purely a means of maximizing corporate value, but is a manifestation of the managerial-shareholder agency problem.

Based on Allen et al's paper, companies with abundant free cash flow but few investment opportunities are more likely to invest outside the optimal level. However, dividends and debt serve as disciplinary mechanisms to prevent managers from wasting corporate resources. This is in line with the case in Indonesia, where the average free cash flow of companies in Indonesia is only around $10 \%$. In comparison, the average expenditure on dividends reaches $51 \%$ of the company's net profit. The average level of leverage of the company is also quite high at $1.78 \mathrm{x}$, so the company needs to pay attention to its ability to pay company obligations. Thus the possibility of agency problems arises because dividend payments and high leverage can curb the high cash flow of Indonesian companies. Companies tend to use company money for dividend payments and consider financial management more stringently. This makes the company more careful in using its free cash flow.

\subsubsection{The dividend payout ratio and company's sustainability practices}


From the results of the regression in Table 4.10, $t$ count is greater $(\mathrm{df}>120$, $\alpha=0.05, \mathrm{t}$ table $=1.645)$, and the level of significance is smaller than 0.05 , so H04 is rejected. Thus, the dividend payout ratio has a significant effect on the company's sustainability practices in a positive direction, which is indicated by the coefficient value $\beta=1.850$.

Table 4.10. Model D Multiple Regression Results

\begin{tabular}{|c|c|c|c|c|c|c|}
\hline \multirow[t]{2}{*}{ Model } & & \multicolumn{2}{|c|}{$\begin{array}{l}\text { Unstandardized } \\
\text { Coefficients }\end{array}$} & \multirow{2}{*}{$\begin{array}{c}\text { Standardized } \\
\text { Coefficients }\end{array}$} & \multirow[t]{2}{*}{$\mathrm{T}$} & \multirow[t]{2}{*}{ Sig. } \\
\hline & & B & Std. Error & & & \\
\hline \multirow{5}{*}{ D } & (Constant) & -5.904 & 7.332 & & -0.805 & 0.422 \\
\hline & TOBINSQ & -0.013 & 0.012 & -0.160 & -1.013 & 0.313 \\
\hline & LN_SIZE & 0.313 & 0.232 & 0.125 & 1.351 & 0.179 \\
\hline & ROE & 1.879 & 1.096 & 0.289 & 1.714 & 0.089 \\
\hline & DPR & 1.850 & 0.624 & 0.258 & 2.966 & 0.004 \\
\hline
\end{tabular}

Mohammed [29] suggests that a high dividend payout policy is a good signal to signify the reputation of a company that cares about the company's financial stakeholders. He also found empirical evidence that supports the statement that companies that have high CSR ratings make dividend payments with a greater amount than companies with low CSR ratings. The results of this study are in line with research conducted by Allen et al [4], which suggests that high dividend payments will curb agency problems and cause high CSR ratings for companies that have good management.

From the results of descriptive statistics, the dividend payout ratio of companies in Indonesia has an average dividend payout ratio of $51 \%$. Thus, the 
company allocates more than half of net income to make dividend payments to shareholders. When dividend payments are high (and interest payments are high), cash becomes limited so that management is motivated to run the company more efficiently and care more about the company's long-term [4]. Companies can use their dividend policy to manage agency problems [29]. Dividend policy can play a role in controlling the problem of excessive investment in CSR so that CSR activities can be managed efficiently and create CSR that has a high rating in terms of economic, social, and environmental.

\subsubsection{Leverage and company's sustainability practices}

From the regression results in table 4.11, the significance level is smaller than 0.05 , so $\mathrm{H} 05$ is rejected. The leverage has a significant negative effect on the company's sustainability practices. Based on the CSR's good governance view, companies with strong leverage generally try to minimize expenditures for nonessential and urgent needs, especially doing voluntary CSR activities. With high leverage, management tends to use company resources to make payments to creditors, thereby reducing the possibility of waste of company resources [4]. As Michael's [25] study shows, debt can curb agency costs from free cash flow by reducing the cash flow available for management expenses.

Table 4.11. Model E Multiple Regression Results

\begin{tabular}{|c|c|c|c|c|c|c|}
\hline \multirow{2}{*}{ Model } & & \multicolumn{2}{|c|}{$\begin{array}{l}\text { Unstandardized } \\
\text { Coefficients }\end{array}$} & \multirow{2}{*}{$\begin{array}{c}\text { Standardized } \\
\text { Coefficients }\end{array}$} & \multirow[t]{2}{*}{$\mathrm{T}$} & \multirow{2}{*}{ Sig. } \\
\hline & & B & Std. Error & & & \\
\hline \multirow{2}{*}{$\mathrm{E}$} & (Constant) & -10.118 & 7.211 & & -1.403 & 0.163 \\
\hline & TOBINSQ & -0.002 & 0.010 & -0.025 & -0.199 & 0.843 \\
\hline
\end{tabular}




\begin{tabular}{|l|l|r|r|r|r|r|} 
& LN_SIZE & 0.492 & 0.230 & 0.187 & 2.139 & 0.034 \\
\hline ROE & 3.176 & 0.907 & 0.495 & 3.500 & 0.001 \\
\hline LEV & -0.382 & 0.087 & -0.453 & -4.360 & 0.000 \\
\hline a. Dependent Variable: ESG
\end{tabular}

The average leverage in Indonesia is $1.78 x$, which indicates that companies in Indonesia have high leverage ratios, so they must better manage the solvency of the company. The greater the leverage ratio, the less spending money on CSR activities. Mohammed's research [29] examines the relationship of leverage, dividends, and CSR. Lenders financially limit companies with high leverage ratios. Based on the explanation above, companies with a high degree of leverage focus on the efficiency of company resources and managing the solvency of the company to fulfill its obligations. Also, companies also have a low ability to be involved in CSR activities. Both of these causes companies with high levels of leverage tend to produce low CSR ratings.

\section{Conclusion}

Based on empirical testing, this study found that cash holdings, free cash flow, and dividend payout ratios have a significant and positive effect on the company's sustainability practices. Capital expenditure does not have a significant effect on the company's sustainability practices, while leverage has a significant negative effect on the company's sustainability practices. Companies in Indonesia tend to be able to take advantage of investment opportunities and focus on the interests of shareholders; hence, high cash holdings can be well managed. Free cash flow in Indonesia tends to use for dividend payments, 
reaching an average of $51 \%$ of the company's net profit. The level of leverage of companies in Indonesia is also quite high in which the companies must maintain their ability to ensure the fulfillment of obligations to creditors. Therefore, management is motivated to run the company more efficiently and invest in highquality CSR programs and this mechanisms able to curb the agency problems. Overall, in line with the view of good governance in CSR, companies that curb agency problems would have high CSR ratings.

Sustainability reporting is predicted to increase in 2019 onwards due to new OJK regulation. Future research can have more samples to gain a broader view. Future research might also examines the relationship between agency problems and sustainability practices solely for the financial industry which has not yet widely discussed in Indonesia. 


\section{References}

[1] Adrian Cheung. Corporate social responsibility and corporate cash holdings. Journal of Corporate Finance. 2016.

[2] Alexander Dyck, Karl Lins, Lukas Roth, Hannes Wagner. Do institutional investors drive corporate social responsibility? Intermational evidence. Journal of financial economics. 2019: 131(3); 693-714.

[3] Ali Darwin. Laporan berkelanjutan masih bersifat voluntary. Republika website. Available from: https://www.republika.co.id/berita/koran/csrkoran/15/12/22/nzr2972-laporan-berkelanjutan-masih-bersifat-voluntary.

[4] Allen Ferrell, Liang Hao, Luc Renneboog. Socially responsible firm. Journal of Financial Economics. 2016: 585-606.

[5] Amarjit Gill, Charul Shah. Determinants of corporate cash holdings: Evidence from Canada. International Journal of Economics and Finance. 2012.

[6] Andrew W Ghillyer. Business Ethics Now. 4th Edition. New York: McGraw-Hill; 2014.

[7] Betty Moy Huber, Michael Comstock. ESG reports and ratings: what they are, why they matter. Available from: https://corpgov.law.harvard.edu/2017/07/27/esg-reports-and-ratings-whatthey-are-why-they-matter/.

[8] Caroline Flammer. Corporate social responsibility and shareholder reaction: the environmental awareness of investors. Academy of Management Journal. 2013: 758-781. 
[9] Christine A Mallin. Corporate Governance. 4rd Edition. Oxford: Oxford University Press; 2013.

[10] Clara Xiaoling Chen, Hai Lu, Theodore Sougiannis. The agency problem, corporate governance, and the asymmetrical behavior of selling, general, and administrative costs. Contemporary Accounting Research. 2012: 252282.

[11] Damodar N Gujarati. Basic Econometrics. 4th Edition. McGraw-Hill Companies; 2004.

[12] Erica Yip, Chris van Staden, Steven Cahan. Corporate social responsibility reporting and earnings management: The role of political costs. Australasian Accounting Business \& Finance Journal. 2011; 17-33.

[13] Global Reporting. About sustainability reporting. Available from: https://www.globalreporting.org/information/sustainability-reporting/Pages/ default.aspx.

[14] Hoje Jo, Maretno A. Harjoto. Corporate governance and firm value: The impact of corporate social responsibility. Journal of Business Ethics. 2011: 351-383.

[15] Hoje Jo, Maretno A. Harjoto. The causal effect of corporate governance on corporate social responsibility. Journal of Business Ethics. 2012.

[16] Imam Ghozali. Aplikasi analisis multivariete dengan program IBM SPSS 23. Semarang: Badan Penerbit Univrsitas Diponegoro; 2016.

[17] Industry Today. Mandatory sustainability reporting. Weblog. Available from: https://industrytoday.com/mandatory-sustainability-reporting/. 
[18] Ioannis Ioannous, George Serafeim. Corporate Sustainability: A Strategy?. Working Paper Harvard Business School. 2019.

[19] Jiraporn, Chintrakarn. How do powerful CEOs view corporate social responsibility (CSR)? An empirical note. Economics Letters. 2013: 344347.

[20] Juniati Gunawan. Mengukur kinerja tanggung jawab sosial perusahaan. Weblog. Available from: https://www.ncsr-id.org/2009/09/02/mengukurkinerja-tanggung-jawab-sosial-perusahaan/.

[21] Kementerian PPN (Bappenas). Apa Itu SDGs. Available from: http://sdgsindonesia.or.id/

[22] Kitzmueller, Shimshack. Economic perspectives on corporate social responsibility. Journal of Financial Economics. 2012: 304-325.

[23] Kontan. Dari 438 emiten, hanya 25 perusahaan yang membuat laporan berkelanjutan. Weblog. Available from: https://investasi.kontan.co.id/news/dari-438-emiten-hanya-25-perusahaanyang-membuat-laporan-berkelanjutan.

[24] Maretno A. Harjoto. the impact of corporate social responsibility on risk taking and firm value. Journal of Business Ethics. 2018.

[25] Michael C Jensen. Agency cost of free cash flow, corporate finance and takeovers. The American Economic Review. 1986.

[26] Michael C Jensen, William H. Meckling. Theory of the firm: Managerial behavior, agency costs and ownership structure. Journal of Financial Economics. 1976: 305-360. 
[27] Michael R. Lewis. Menghitung return on equity (ROE). Wikihow website. Available from: https://id.wikihow.com/Menghitung-Return-on-Equity(ROE).

[28] Mohamed Arouri, Guillaume Pijourlet. CSR performance and the value of cash holdings: International evidence. Journal of Business Ethics. 2017.

[29] Mohammed Benlemlih. Corporate social responsibility and dividend policy. Research in International Business and Finance. 2019: 114-138.

[30] Otoritas Jasa Keuangan. Sustainability report bagi Lembaga jasa keuangan dan emiten. Available from: https://www.ojk.go.id/sustainablefinance/id/publikasi/riset-dan-statistik/Pages/Sustainability-Report-bagiLembaga-Jasa-Keuangan-dan-Emiten.aspx).

[31] Robert C Higgins, Jennifer L Koski, Todd Mitton. Analysis for financial management. New York: Mc.Graw Hill Education; 2016.

[32] Ronald Masulis, C Wang, F Xie. Agency problems at dual-class companies. Journal of Finance. 2009: 1697-1727.

[33] Ronald Masulis, Syed Walid Reza. Agency problems of corporate philanthropy. Review of Financial Studies. 2015: 592-636.

[34] Stephen A Ross, Randolph W Westerfield, Jeffrey Jaffe, Bradford D Jordan. Corporate Finance. 11th Edition. New York: McGraw-Hill Education; 2016.

[35] Taufik Hidayat, Nina Istiadah. Panduan lengkap menguasai SPSS 19 untuk mengolah data statistik penelitian. Jakarta: Mediakita; 2011.

[36] United Nation. Sustainable Development Goals Knowledge Platforms. Available from: 
https://sustainabledevelopment.un.org/memberstates/indonesia.

[37] United Nations Industrial Development Organization. What is CSR? Available from:https://www.unido.org/our-focus/advancingeconomic/competitiveness/ competitive-trade-capacities-and-corporate-responsibility/corporate-socialresponsibility-market-integration/what-csr.

[38] Xie, Nozawa, Yagi, Fujii, Managi. Do environmental, social, and governance activities improve corporate financial performance?. Business Strategy and the Environment. 2019. 